\title{
Framing: förståelseram eller kontextualisering?
}

\section{Av Bärbel Westphal, doktorand i tysk litteraturvetenskap vid Uppsala universitet, verksam i Växjö}

\author{
Länk till presentation av Bärbel Westphal
}

\section{Inledning}

Den engelskspråkiga forskningslitteraturen har sedan mitten av nittonhundratalet fått en framskjuten plats i den globala forskarbyn. Det är därför inte förvånande att de svenska bibliotekens databas Libris innehåller 141 träffar på ordet framing. Begreppet framing förekom visserligen i internationella vetenskapliga sammanhang redan 1859, men en omfattande ökning är helt tydlig från början av 1980-talet till idag. Frånsett begreppets användningsområde inom arkitektur, fotokonst och konstvetenskap ligger tyngdpunkten idag inom det sociologiska och litteraturvetenskapliga fältet, men det förekommer även inom psykologi, lingvistik, antropologi, pedagogik och cultural studies. Som framgår av titelförteckningen i Libris betyder framing i de flesta fall ungefär 'fokusering på något, ett problems närmare definition, rambetingelser eller förståelsehorisont'. Exempel på några titlar är: Cultural frames, framing culture (2000), Framing Shakespeare (2000), The Framing of Socrates (1998), The rhetoric of the frame (1996) och Framing and Fiction (1992). Begreppet framing har för en bredare krets inom litteraturvetenskapen fr a blivit känt genom Jonathan Cullers Framing the Sign (1988).[1] Då det dock ännu saknas en svensk översättning av verket har ordet hittills inte fått någon svensk motsvarighet. I denna presentation av narratologins använding av framingteorin kommer jag att använda ordet ram.

En ökad användning av engelska som vetenskapsspråk märks även i tyskspråkiga länder. Därför finner den som sysslar med tysk litteraturvetenskap begrepp som lånas direkt från engelskan utan fullgod översättning till tyskan. I tysk narratologisk forskning har begreppet förts in via kognitionsforskningen, och på det viset har en länk skapats mellan strukturell narratologisk analys och receptionsestetisk hermeneutik.

Denna artikel ska utförligt visa på det sistnämnda sambandet och redogöra för de resonemang som förs i dagens narratologiska forskning i Tyskland. Dessutom ska begreppets användning i den litteraturvetenskapliga textanalysen och dess avgränsning mot den s k kontextualiseringen diskuteras, dock mera kortfattat. Detta sker utifrån de australiensiska litteraturvetarna Gale MacLachlans och Ian Reids framställning Framing and Interpretation (1994).[2] Begreppets enorma utbredning föranledde nämligen MacLachlan och Reid att ge en överblick över de olika forskningsfältens användning av framingmetaforen, detta även för att kunna främja tvärvetenskapliga projekt som har liknande utgångspunkter. Eftersom det inte är möjligt att återge resultaten från alla områden som författarna tar upp, koncentreras framställningen i det sista kapitlet främst på några generella funderingar kring begreppet.

\section{Framing och narratologi}

Framingteorin kommer ursprungligen från forskningen om konstgjord intelligens (Minsky 1975). Där skiljer man mellan schema (större temporär enhet), plan (målinriktat koncept) och script (minsta enhet, stereotyp, fast kulturellt bundet förlopp). Schank\&Abelsons (1977) berömda exempel är restaurang-scriptet: "Han gick in på stadshotellet, satte sig och 
njöt av maten", är en mening som framkallar färdiga ramar i vår hjärna. Vi vet, i alla fall i vår kulturkrets, att mannen också måste prata med en kypare, beställa mat och sedan betala den. För detta fenomen använder Perry (1979) två år senare endast begreppet frame, alltså ram.[3] Ramen talar om för oss hur vi ska förstå en situation. Ramen är dock inte något fixt och färdigt utan har det som på engelska benämns slots, slussar, öppningar eller utvägar som möjliggör en ändring av vårt synsätt. När vi läser en text måste vi tillskriva tal- och tankeåtergivning rätt figurer, vi måste begripa oss på en ironisk kommentar från berättaren osv. Detta gör vi allteftersom och enligt hur sannolikt det är att berättelsen har skiftat till ett annat plan eller en annan figur eller en annan tid. Det låter sig inte alltid lätt göras. Ett exempel på detta är James Joyce Ulysses. Ändå har vi strategier eller ramar som möjliggör en viss textförståelse. En enkel omställning av identiska meningar gör att perspektivet skiftar:

[a] Rummet var mörkt. [b] Sven öppnade dörren och gick in i rummet.

[b] Sven öppnande dörren och gick in i rummet. [a] Rummet var mörkt.

I den första meningen förstår vi att det måste vara en berättare som vet att rummet är mörkt. Vi ser Sven från ett utifrånperspektiv. I den andra meningen är det Sven själv som upptäcker att rummet är mörkt. Vi ser skeendet genom Svens ögon. Det här exemplet visar att det finns ett samband mellan textstrukturen och hur vi närmar oss en text. Strukturen kan leda eller till och med vilseleda vår läsning. Som läsare är vi, i alla fall när vi läser något för första gången, hänvisade till att följa textens förlopp. Under läsningens gång kommer vi att behöva ompröva våra förståelseramar ett antal gånger. Dock måste en djupare och större textbetydelse härledas ur textens helhet och ses i en större kontext än i två isolerade meningar. Icke desto mindre visar exemplet att styrningen av läsprocessen även sker på satsnivå.

Denna överföring av kognitionsforskningens resultat till den narratologiska analysen är en vidareutveckling, en ny vinkling av de dittills dominerande lingvistiska influenserna. 1990 myntade den holländske forskaren Elrud Ibsch begreppet "the cognitive turn".[4] Med detta uttryck betecknade han en tendens som efter "the linguistic turn" fann sin utbredning inom 80-och 90-talets narratologi. Redan 1977 hade Van Dijk\&W. Kintsch i "Recalling and summarizing stories" försökt att relatera narratologiska strukturelement till kognitiva processer som t ex textförståelse och minne.[5] Ibsch hänvisar till ett antal tyska undersökningar från andra hälften av 1980-talet som alla utgått från narratologins grundkoncept, vilket kort kan beskrivas som en metod att genom analys av berättartekniska element strukturera en text för att på så sätt åstadkomma en textförståelse.[6] Dessa projekt gav sig kritiskt i kast med att på ett empiriskt sätt undersöka det påstådda sambandet mellan textelement, berättarperspektiv och betydelser. Man lät ett stort antal testpersoner läsa texter och textvarianter och försökte komma fram till vilka berättartekniska strategier det är som har störst betydelse för uppkomsten av olika läsarter. Ibsch kan i sin överblick konstatera att alla kommer fram till en gemensam slutsats: textelement är inga givna och färdiga byggstenar med en viss given innebörd kopplad till sig, utan betydelsen konstrueras utifrån läsaren. Visserligen kan en narratologisk analys förbereda ett fundament för textanalys men en texttolkning måste sedan ske utifrån forskarens perspektiv. Det narratologiska perspektivet knyter här an till receptionsteoretiska tankesätt. Textförståelsen utgår från läsarens kognitiva disposition. Varje läsare förenklar den komplexa strukturen som en text erbjuder till för honom begripbara sekvenser. Rekonstruktionen av aktantmodellen byggs alltså på mänskliga grunderfarenheter. Detta kan, starkt förenklat, ses som själva grundantagandet för framingteorin.

\section{Framingbegreppet och fokaliseringsproblematiken inom erlebte Rede}

Faulstich/Ludwig (1985) konstaterar i Erzählperspektive empirisch att det för texttolkningen finns mer eller mindre relevanta kategorier. Om berättelsen berättas i första eller tredje person eller om den berättas med homo- eller heterodiegetisk berättare har minst effekt på textförståelsen. Vad som däremot faktiskt påverkar tolkningen är 
berättarmodus; alltså om skeendet återges med telling/showing-tekniker, d v s direkt tal, indirekt tal, inre monolog, eller erlebte Rede (free indirect discourse). Moduset erlebte Rede är nära förbundet med fokaliseringsproblematiken. Fokalisering definierar jag enligt Kablitz (1988) som en perceptionsprocess inom det fiktiva skeendet.[7] Forskare har i snart hundra år funderat på om det är berättaren som styr eller om det är figuren som i det närmaste övertar berättandet. Hur långt går vi in i figurens medvetande? Var avslöjar berättaren egentligen sig själv? Hur påverkar figurens och berättarens stil och idiom varandra? Hur kan vi avgöra om det ena eller andra perspektivet tar över? Lingvister har sökt markörer för den enes övertag över det andra. [8] Dessa frågor är även intressanta för den inre monologen som har en del gemensamt med erlebte Rede. Tolkningen att det är figuren som i det närmaste talar självständigt var särskilt stark under de år då litteraturteorin proklamerade att "berättaren var död". En allmänt accepterad tes har dock länge varit Roy Pascals (1977) antagande om den dubbla rösten i erlebte Rede.[9] I Tyskland har detta forskningsfält knutit an till framingteorin. Manfred Jahn (1997) använder rambegreppet för att komma vidare i frågan om den dubbla rösten i moduset erlebte Rede, där man ju kan förnimma både berättarens och figurens röst.[10] En jämförelse mellan tre modus kan här belysa moduset erlebte Rede.

Direkt tal: Sara frågade förnärmat: "Är jag inte värd att få ett pris"?

Indirekt tal: Sara frågade förnärmat om inte hon var värd att få ett pris.

Erlebte Rede: Skulle inte hon vara värd att få ett pris?

Enligt Jahn är erlebte Rede en från direkt och indirekt tal förskjuten konstruktion. Som exemplet ovan visar sker en förskjutning i tempus och pronomen trots att det är till synes figurens egna tankar. Denna konstruktion, ram 1 kan övergå i ram 2 som uteslutande representerar figurens perceptionssperspektiv. Ram 1 och 2 kan också gå över i berättarens diskurs. Enligt Jahn är antagandet om den dubbla rösten förståelig med hjälp av framingteorin och går att förklara utan att man behöver lingvistiska verktyg. Man kan både skilja på två röster och avgöra i vilken situation den ena eller andra rösten får övertaget. Likt två fönster som är öppna på datorskärmen kan fönstren ligga bredvid varandra eller täcka varandra helt eller delvis. På liknande sätt förstår vi det vi läser i en förstahandstolkning och håller fast vid vårt synsätt tills texten tvingar oss att tänka om. Först när indicierna blir tillräckligt starka för en omtolkning öppnar vi ramen och kliver in i nästa. Erlebte Rede är enligt detta inget konstant modus utan kan skifta mer åt berättarens eller mer åt figurens håll. Ofta finns på berättarsidan ett spår av ironiskt avståndstagande gentemot figurens handlande och tankesätt.

Vid en konfrontation med flerdimensionella tavlor kan man göra sig en föreställning om hur hjärnan arbetar hos en människa: att man först alltid ser en viss möjlighet. Efter ett tag verkar hjärnan tröttna och levererar ett annan synsätt. Man har dock aldrig de båda möjligheterna simultant framför sig. Vi utgår från en ramförståelse för att efterhand ompröva och modulera vår första idé om meningen med det vi ser eller läser. Nya indicier kan leda till att vi helt byter åsikt. Detta är den kognitiva förklaringen till att interpretationer kan stå bredvid varandra och konkurrera med varandra, men vi utgår alltid från ett visst synsätt från början. För narratologin har skiftet från den lingvistiska ansatsen till den kognitiva betytt en större frihet för tolkningen av det icke entydiga moduset erlebte Rede.

\section{Framing: ram eller kontext?}

Medan kognitionsforskningen använder begreppet kontext ganska okritiskt som den baskunskap framkallandet av en ram grundar sig på, har litteraturvetenskapen inte längre något enkelt förhållande till begreppet kontext. Kontexterna är många: de kan vara sociokulturella och institutionella och härröra från klass, genus och etnicitet, etc. Mary Douglas menar i Purity and Danger (1966) att kulturella ramar innesluter önskvärda ämnen och stänger ute icke önskvärda.[11] De kontexterna vi har tillgång till är i den socialiseringsprocess vi alla går igenom redan i viss mån avgränsade, antingen tillåtna eller 
tabubelagda. Kontexten kan alltså inte enkelt reduceras till kunskap om världen.

När det gäller textanalysen skiljer MacLachlan\&Reid på intratextuella, extratextuella och circumtextuella ramar, det senare står för allt material som omger t ex en bok såsom omslaget, bibliografin eller den grafiska gestaltningen. Insikten om all kunskaps rekonstruktion, interpretation och avgränsning gör att skillnaden mellan text och kontext inte längre är knivskarp. Detta resonemang finns redan i Cullers Framing the Sign där han föreslår att termen kontext ersätts med just framing. Eftersom även etablerandet av kontexten är resultatet av en process, ett aktivt urval, avspeglar begreppet framing på ett mera tydligt sätt att det handlar om en aktivitet. Därför föredrar MacLachlan och Reid också termen framing och inte substantiven frame eller framework när de hänvisar till Derridas formulering att "framing occurs but there is no frame".[12] Jag skulle vilja uttrycka det så att ramarna både finns och konstrueras. De befintliga ramarna har konstruerats i en samhällsdiskurs. I den process som innebär att individen orienterar sig i världen både stöter den på givna ramar och konstruerar nya, förmodligen i samarbete med andra. Definitioner, uppfattningar om världen, läsarter o s v är därmed ständigt stadda i förändring.

Ramen bär också på en viss dubbelhet. För att dra nytta av själva metaforen: när ett konstverk betraktas på ett galleri kan ramen både ses som en del av konstverket och som en del av den omgivande väggen. Framing är alltså något som både inkluderar och exkluderar. När en text, ett konstverk, eller vilken aktivitet som helst ska beskrivas måste de både sättas in i en större kontext, men också avgränsas från andra, olikartade aktiviteter. En kriminalroman är en fiktional berättelse, men inte en reseberättelse, barnbok etc. Stanley Fish (1980) använder t o m begreppet ram som verktyg för att definiera litteratur. Litteratur är "a language around which we have drawn a frame".[13] Detta kollektiva "we" lär enligt min mening ständigt ompröva och ändra sina ramar. Litteratur kommer därför att definieras olika i olika tider. Varje företeelses definition vilar därmed på en avgränsning som är mer än ett insättande i ett sammanhang. Den större omgivande kontexten kommer dessutom återigen att utsättas för en framing, då man väljer ut det område som ska sammanföras med den primära texten. Därför ger framing, eftersom ett bra ord för det i svenskan saknas, faktiskt en mer adekvat beskrivning än t o m den svenska aktivitetsformen kontextualisering. Det kan emellertid också vara så att dessa begrepp betonar olika aspekter av samma skeende.

När man tar in kontexten både vidgar man fältet och ger sig in på ett större fält än själva texten erbjuder. Framing är däremot en aktivitet som i viss mån begränsar.

Texten/kontexten ses som genom ett filter, en ram som man väljer ut. Därmed begränsas textfältet igen. Framing påminner oss om att alla redan från början läser med vissa gränser och förutsättningar. Här finns faktiskt överensstämmelsen med kognitionsforskningens rambegrepp. Kanske har vi härmed kommit tillbaka till den hermeneutiska skolans begrepp förståelsehorisont, fast denna gång med utgångspunkt i att full och säker insikt aldrig kan nås om vare sig text eller kontext.

\section{(C) Bärbel Westphal}

[1] Culler, Jonathan 1988. Framing the Sign. Oxford: Blackwell.

[2] MacLachlan, Gale; Reid, Ian 1994. Framing and Interpretation. Melbourne.

[3] Minsky, Marvin 1980. A Framework for Representing Knowledge. In: Metzing, Dieter (ed.): Frame Conceptions and Text Understanding. New York: de Gruyter. 1-25. Perry, Menakhem 1979. Literary Dynamics: How the Order of a Text Creates Its Meanings. Poetics Today. 1-2: 35-64; 311-61.

Schank, Roger C.; Abelson, Robert B. 1977. Scripts, plans, goals and understanding: an inquiry into human knowledge structures. Hillsdale, N.J.: LEA.

[4] Ibsch, Elrud 1990. The cognitive turn in narratology. In: Poetics Today 11: 411-18.

[5] Van Dijk, T.A. ; W. Kintsch 1977. Cognitive Psychology and Discourse: Reading and Summarizing Stories. In: Current Trends in Textlinguistics. 61-80. 
[6] Lászlo Halász (ed.) 1987. Literary Discourse: Aspects of Cognitive and Social Psychological Approaches. Berlin: de Gruyter.

Peter Vorderer; Norbert Groeben (ed.)1987. Textanalyse als Kognitionskritik?

Möglichkeiten und Grenzen ideologiekritischer Inhaltsanalyse. Tübingen: Narr.

Hans Werner Ludwig; Werner Faulstich 1985. Erzählperspektive empirisch -

Untersuchungen zur Rezeptionsrelevanz narrativer Strukturen. Tübingen: Narr.

[7] Kablitz, Andreas 1988. Erzählperspektive, Point of View, Focalisation. Überlegungen

zu einem Konzept der Erzähltheorie. In: Zeitschrift für französische Sprache und Literatur.

Wiesbaden. 98: 237-255.

[8] Till denna problematik se: Fludernik, Monika 1993. The Fictions of Language and the

Languages of Fiction. The Linguistic Representation of Speech and Consciousness.

London: Routledge.

[9] Pascal, Roy 1977. The dual voice. Free Indirect Speech and it's Functioning in the

Nineteenth-Century European Novel. Manchester.

[10] Jahn, Manfred 1997. Frames, Preferences, and the Reading of Third-Person

Narratives: Towards a Cognitive Narratology. In: Poetics Today. 18; 4: 441-68.

[11] Douglas, Mary 1966. Purity and Danger. London: Routledge.

[12] MacLachlan; Reid 1994:9.

[13] MacLachlan; Reid 1994:91. 